\title{
Angiotensin-Converting Enzyme
}

National Cancer Institute

\section{Source}

National Cancer Institute. Angiotensin-Converting Enzyme. NCI Thesaurus. Code C91297.

Angiotensin-converting enzyme (1306 aa, $150 \mathrm{kDa}$ ) is encoded by the human ACE gene. This protein plays a role in the hydrolysis of angiotensin I to form angiotensin II and the solubilization of glycophophoinositol-anchored proteins from the plasma membrane. 